\title{
Freqüência de dermatoses infecciosas em 208 pacientes transplantados renais*
}

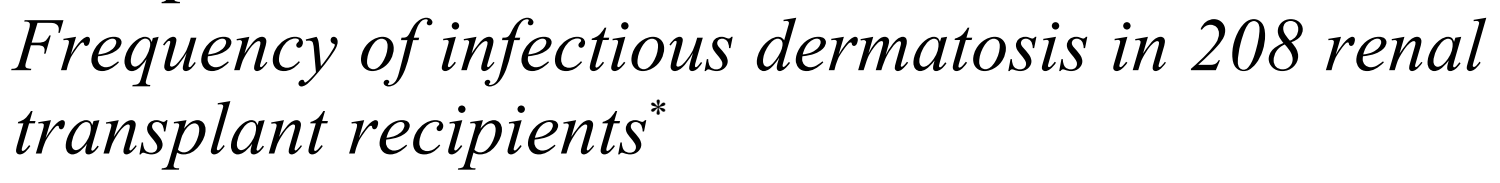

Gérson Vettorato

\author{
André Vicente Esteves de Carvalho \\ Valter Duro Garcia ${ }^{5}$
}

\author{
Sérgio Martinez Lecompte \\ Elizete Keitel ${ }^{6}$
}

Resumo: FUNDAMENTOS - Nos pacientes transplantados renais, a imunossupressão crônica acarreta maior suscetibilidade às dermatoses infecciosas.

O BJETIVOS - avaliar a freqüência de dermatoses infecciosas em 208 pacientes transplantados renais no período de 12 meses e verificar a relação entre sua ocorrência e o período de tempo transcorrido desde o transplante.

MÉTODO - 208 transplantados renais de uma população de 720 pacientes foram submetidos a exame dermatológico no período de um ano, tendo sido realizados exames anatomopatológico micológico, bacteriológico e/ou cultural das lesões suspeitas.

RESULTADOS - a freqüência de dermatoses infecciosas nessa população foi de 89,4\%. As infecções fúngicas, virais, bacterianas e parasitárias mais freqüentes foram pitiríase versicolor $(17,8 \%)$, verruga vulgar $(32,2 \%)$, foliculite $(4,3 \%)$ e escabiose $(3,8 \%)$.

CONCLUSÃO - as dermatoses infecciosas são freqüentes nos pacientes transplantados renais, e sua ocorrência aumenta progressivamente conforme o tempo transcorrido a partir do transplante, sendo importante o acom panhamento dermatológico desses pacientes.

Palavras-chave - dermatopatias infecciosas; imunossupressão; transplante de rim.

Summary: BACKGROUND - Chronic immunosuppressive therapy predisposes renal transplant recipients to a beightened susceptibility to infectious dermatoses.

OBJECTIVES: evaluate the frequency of infectious dermatoses in 208 renal transplant recipients over a 12-month period and verify the relation between the onset of dermatoses and the time elapsed since transplantation. METHOD: 208 renal transplant recipients, taken from a population of 720 transplant recipients, received a dermatological examination for a year. Dermatopatbological examination, mycological examination, bacteriologic examination, and cultures were taken from suspected lesions.

RESULTS: the prevalence of infectious dermatosis was $89.4 \%$ in this population. The more frequent fungal, viral and bacterial infections were respectively pitiyriasis versicolor (17.8\%), warts (32.2\%), and folliculitis (4.3\%). CONCLUSION: infectious dermatoses are common in renal transplant recipients. Their occurrence is progres sively higher as time passes after the transplantation, therefore making the frequent dermatological examination of these recipients very important.

Key words: skin diseases, infectious; immunosuppression; kidney transplantation.

Recebido em 02.01.2002. / Received in January, $02^{\text {nt }}$ of 2002.

Aprovado pelo Conselho Consultivo e aceito para publicação em 14.08.2002. / Approved by the Consultive Council and accepted for publication in August, $14^{\text {th }}$ of 2002.

* Trabalho realizado no Serviço de Dermatologia da UFRGS e Serviço de Transplante Renal. Complexo Hospitalar Santa Casa. Porto Alegre - RS, Brasil. / Work done at "Dermatology

Service at the UFRGS and Renal Transplant Service. Complexo Hospitalar Santa Casa. Porto Alegre, RS, Brazil".

${ }^{l}$ Médico Dermatologista responsável pelo Setor de Micologia do Serviço de Dermatologia da UFRGS. Complexo Hospitalar Santa Casa. Porto Alegre - RS, Brasil. / Dermatologist in charge of the Mycology Sector of the Dermatology Service at UFRGS. Complexo Hospitalar Santa Casa. Porto Alegre, Rio Grande do Sul state (RS), Brazil.

${ }^{2}$ Médico Dermatologista. Ex-residente do Serviço de Dermatologia da UFRGS. Complexo Hospitalar Santa Casa. Porto Alegre - RS, Brasil. / Dermatologist. Former-resident of the

Dermatology Service at UFRGS. Complexo Hospitalar Santa Casa. Porte Alegre, RS, Brazil.

${ }^{3}$ Residente do Serviço de Dermatologia da UFRGS. Complexo Hospitalar Santa Casa. Porto Alegre - RS, Brasil. / Resident of the Dermatology Service at UFRGS. Complexo Hospitalar Santa Casa. Porto Alegre, RS, Brazil.

${ }^{4}$ Residente do Serviço de Dermatologia da UFRGS. Complexo Hospitalar Santa Casa. Porto Alegre - RS, Brasil. / Resident of the Dermatology Service at UFRGS. Complexo Hospitalar Santa Casa. Porto Alegre, RS, Brazil.

${ }^{5}$ Médico Nefrologista. Chefe do Serviço de Transplante Renal. Complexo Hospitalar Santa Casa. Porto Alegre - RS, Brasil. / Nephrologist. Head of the Renal Transplant Service.

Complexo Hospitalar Santa Casa. Porto Alegre, RS, Brazil.

${ }^{6}$ Médica Nefrologista. Serviço de Transplante Renal. Complexo Hospitalar Santa Casa. Porto Alegre - RS, Brasil. / Nephrologist. Renal Transplant Service. Complexo Hospitalar Santa Casa. Porto Alegre, RS, Brazil. 


\section{INTRODUÇÃO}

A imunossupressão prolongada tem aumentado a sobrevida dos pacientes transplantados renais. Em decorrência dessa imunossupressão crônica que influencia os mecanismos de defesa imune do paciente, levando à diminuição da imunidade celular, há aumento da suscetibilidade a diversas dermatoses infecciosas. ${ }^{1}$

O objetivo do presente estudo é analisar a freqüência de dermatoses fúngicas, virais, parasitarias e bacterianas em um grupo de 208 pacientes transplantados renais em terapia imunossupressiva.

\section{MATERIAL E MÉTODOS}

De abril de 2000 a abril de 2001, 208 pacientes transplantados renais de um universo de 720 pacientes foram avaliados no Serviço de Dermatologia da Universidade Federal do Rio Grande do Sul, Complexo Hospitalar Santa Casa, o que determina erro amostral de $5,7 \%$ com grau de confiabilidade de 95\%. Dos 208 pacientes, $117(56,5 \%)$ eram do sexo masculino, e 90 $(43,5 \%)$, do sexo feminino, com idade entre oito e 79 anos. O período de tempo decorrido desde o transplante variava entre 30 dias e 25 anos. Nessa população, 10 protocolos diferentes de terapia imunossupressora estavam sendo utilizados, prescritos conforme as condições clínicas do paciente, histocompatibilidade, tipo de doador (cadáver ou vivo) e época em que ocorreu o transplante.

Foram realizados anamnese e exame dermatológico de todos os pacientes e solicitados exames anatomopatológicos e laboratoriais quando havia suspeita clínica de dermatoses infecciosas. De acordo com o tipo de lesão, o paciente era encaminhado para um ou mais dos seguintes exames: biópsia cutânea, exame bacteriológico (gram e cultura de secreções), exame micológico direto e cultura, e pesquisa de ácaros.

Verificou-se a freqüência de dermatoses infecciosas fúngicas, virais, parasitárias e bacterianas nos 208 pacientes, bem como a relação entre a ocorrência de tais dermatoses e o tempo transcorrido desde o transplante, dividindo-se, nesse sentido, os pacientes em três grupos: grupo 1 (menos de um ano), grupo 2 (de um a cinco anos), grupo 3 (mais de cinco anos). Esses dados foram analisados utilizando o programa EPIINFO 2000 versão 1.0, sendo os resultados apresentados a partir da freqüência em que ocorreram essas dermatoses infecciosas.

\section{RESULTADOS}

As infecções fúngicas superficiais foram as mais freqüentes, perfazendo $40,9 \%$ de todas as dermatoses infecciosas. A pitiríase versicolor foi encontrada em 37 pacientes $(17,8 \%)$, apresentando-se geralmente de forma disseminada, com grande número de lesões. As dermatofitoses ocorreram em 15 pacientes $(7,3 \%)$ nas seguintes formas clínicas: Tinea corporis em sete pacientes $(3,4 \%)$, Tinea pedis em cinco $(2,4 \%)$, Tinea cruris em dois (1\%), e Tinea manuum em um $(0,5 \%)$. Foram observados oito casos de candidíase cutânea

\section{INTRODUCTION}

Prolonged immunosuppression increases the survival rate of renal transplant recipients. As a result of the chronic immunosuppression that influences recipients' immune defense mechanisms, leading to a decrease of cellular immunity, there is an increase in susceptibility to diverse infectious dermatoses. ${ }^{l}$

The aim of the present study is to analyze the prevalence of fungal, viral, parasitic and bacterial dermatoses in a group of 208 renal transplant recipients undergoing immunosuppressive therapy.

\section{MATERIAL AND METHODS}

From April 2000 to April 2001, 208 renal transplant recipients from a group of 720 recipients were evaluated at the Dermatology Service of the Universidade Federal do Rio Grande do Sul (FRGS), the Complexo Hospitalar Santa Casa. The evaluation showed a sample error of $5.7 \%$ with a 95\% degree of reliability. Among the 208 recipients, 117 (56.5\%) were male and 90 (43.5\%) were female, their ages ranging from 8 to 79 years. The period of time elapsed since the transplant varied from 30 days to 25 years. In this population, 10 different protocols of immunusuppressive therapy were utilized, as prescribed in accordance with the recipient's clinical conditions, histocompatibility, donor type (dead or alive) and the moment at which the transplant took place.

Anamneses and dermatological tests were performed on all recipients and anatomopathological and laboratory tests were solicited when clinical infectious dermatoses were suspected. According to the lesion type, the recipient was directed to one or more of the following tests: cutaneous biopsy, bacteriological test (gram and culture of secretions), direct and cultural mycological tests, and an acarina survey.

Also verified was the frequency of fungal, viral, parasitical and bacterial infectious dermatoses in the 208 recipients, as well as the relation between the occurrence of such dermatoses and the time elapsed since the transplant. The data accumulated split the recipients into three groups: group 1 (less than a year), group 2 (from one to five years), and group 3 (more than five years). These data were analyzed by utilizing the EPIIFO 2000 version 1.0 program. The results showed the frequency at which these infectious dermatoses occur.

\section{RESULTS}

Superficial fungal infections were most frequent, amounting to $40.9 \%$ of all the infectious dermatoses. Pityriasis versicolor was found in 37 recipients (17.8\%), generally appearing in disseminated form, with a large number of lesions. Dermatophytoses occurred in 15 recipients $(7.3 \%)$ in the following clinical forms: Tinea corporis in seven recipients (3.4\%), Tinea pedis in five (2.4\%), Tinea cruris in two (1\%), and Tinea manuum in one (0.5\%). Eight cases were observed of cutaneous candidasis (3.8\%), and 
$(3,8 \%)$, e um paciente $(0,5 \%)$ apresentou feo-hifomicose.

Os agentes mais freqüentes das onicomicoses foram os fungos contaminantes (Aspergillus spp e Fusarium spp), em 10 pacientes $(4,8 \%)$, seguidos pelas onicomicoses por dermatófitos e cândida.

Nas infecções virais, as causadas por HPV foram observadas em 72 pacientes $(34,6 \%)$, sendo a verruga vulgar a mais freqüente, encontrada em 67 pacientes $(32,2 \%)$, e o condiloma acuminado, verificado em apenas cinco pacientes $(2,4 \%)$. Observaram-se lesões de molusco contagioso, herpes simples e herpes-zóster em dois (1\%), quatro $(1,9 \%)$ e dois $(1 \%)$ pacientes, respectivamente.

Ocorreram lesões bacterianas em 11 pacientes $(5,3 \%)$, e em um, micobacteriose atípica (0,5\%), cujo agente não foi possível identificar.

Foi diagnosticada infestação parasitária por Sarcoptes scabiei em oito pacientes $(3,8 \%)$ (Tabela 1). Comparando os três grupos, de acordo com o tempo decorrido desde o transplante, verificou-se que a freqüência da maioria das dermatoses é maior após o primeiro ano de transplante (Tabela 2). one recipient $(0.5 \%)$ showed phaeo-hyphomycosis.

The most frequent onicomycosis agents were the contaminant fungi (Aspergillus spp and Fusarium spp) found in 10 recipients (4.8\%), followed by onicomycoses by dermatophytes and candida.

Viral infections caused by HPV were observed in 72 recipients (34.6\%), with verruca vulgaris being the most frequent, found in 67 recipients (32.2\%) and condyloma acuminatum identified in only five recipients $(2.4 \%)$. Contagious molluscum, herpes simplex and herpes zoster lesions were observed in two (1\%), four (1.9\%) and two recipients (1\%), respectively.

Bacterial lesions occurred in 11 recipients (5.3\%), and in one, atypical mycobacteriosis (0.5\%), whose agent could not be identified.

Eight recipients $(3.8 \%)$ received the diagnosis of parasitic infestation by Sarcoptes scabiei (Table 1). Comparing the three groups, according to the time elapsed since the transplant, the frequency of most dermatoses proved to be greater subsequent to the first year following the transplant (Table 2).

Tabela 1: Freqüência das dermatoses infecciosas em 208 pacientes transplantados renais. Table 1: Frequency of infectious dermatoses in 208 renal transplant recipients.

\begin{tabular}{|c|c|}
\hline $\begin{array}{l}\text { FUNGICAS SUPERFICIAIS / SUPERFICIAL FUNGAL } \\
\text { Ptiríase versicolor / Pityriasis versicolor }\end{array}$ & $37(17.8 \%)$ \\
\hline \multicolumn{2}{|l|}{ Onicomicoses / Onicomycoses } \\
\hline Contaminantes (Aspergillus spp / Fusarium spp) / Contaminantes (Aspergillus spp / Fusarium spp) & $10(4.8 \%)$ \\
\hline Dermatófito / Dermatophytoses & $8(3.8 \%)$ \\
\hline Cândida / Candida & $7(3.4 \%)$ \\
\hline \multicolumn{2}{|l|}{ Dermatofitoses / Dermatophytoses } \\
\hline Tinea corporis / Tinea corporis & $7(3.4 \%)$ \\
\hline Tinea pedis / Tinea pedis & $5(2.4 \%)$ \\
\hline Tinea cruris / Tinea cruris & $2(1 \%)$ \\
\hline Tinea manuum / Tinea manuum & $1(0.5 \%)$ \\
\hline \multicolumn{2}{|l|}{ Leveduras / Yeasts } \\
\hline Candidiase cutânea / Cutaneous candidiasis & $8(3.8 \%)$ \\
\hline \multicolumn{2}{|l|}{ FÚNGICAS PROFUNDAS / DEEP FUNGAL } \\
\hline \multicolumn{2}{|l|}{ Feo-hifomicose / Phaeo-hyphomycosis 1 (0.5\%) } \\
\hline \multicolumn{2}{|l|}{ VIRAIS / VIRAL } \\
\hline Verruga vulgar / Verruca vulgaris & $67(32.2 \%)$ \\
\hline Condiloma acuminado / Condyloma acuminatum & $5(2.4 \%)$ \\
\hline Molusco contagioso / Contagious molluscum & $2(1 \%)$ \\
\hline Herpes simples / Herpes simplex & $4(1.9 \%)$ \\
\hline Herpes-zóster / Herpes zoster & $2(1 \%)$ \\
\hline \multicolumn{2}{|l|}{ BACTERIANAS / BACTERIAL } \\
\hline Foliculite / Folliculitis & $9(4.3 \%)$ \\
\hline Ectima / Ecthyma & $2(1 \%)$ \\
\hline Micobacteriose / Mycobacteriosis & $1(0.5 \%)$ \\
\hline \multicolumn{2}{|l|}{ PARASITÁRIAS / PARASITIC } \\
\hline Escabiose / Scabiosis & $8(3.8 \%)$ \\
\hline
\end{tabular}


Tabela 2: freqüência de dermatoses infecciosas em 208 pacientes transplantados renais. Table 2: frequency of infectious dermatoses in 208 renal transplant recipients.

Tempo de transplante / Time of transplant

\begin{tabular}{|c|c|c|c|}
\hline Dermatoses / Dermatoses & $\begin{array}{l}<1 \text { ano (42 Pacientes) } \\
<1 \text { year (42 recipients) }\end{array}$ & $\begin{array}{l}1-5 \text { anos ( } 77 \text { Pacientes) } \\
1-5 \text { years ( } 77 \text { recipients) }\end{array}$ & $\begin{array}{l}>5 \text { anos ( } 89 \text { Pacientes) } \\
>5 \text { years ( } 89 \text { recipients) }\end{array}$ \\
\hline \multicolumn{4}{|l|}{ Fúngicas superficiais / Superficial fungal } \\
\hline Ptiríase versicolor / Pityriasis versicolor & $6(16.2 \%)$ & $24(64.9 \%)$ & $7(18.9 \%)$ \\
\hline \multicolumn{4}{|l|}{ Onicomicoses / Onicomycoses } \\
\hline Não dermatófitos (Aspergillus spp /Fusarium spp) & $1(10 \%)$ & $4(40 \%)$ & $5(50 \%)$ \\
\hline \multicolumn{4}{|l|}{ Non dermatophytoses (Aspergillus spp /Fusarium spp) } \\
\hline Dermatófito / Dermatophytosis & $2(25 \%)$ & $1(12.5 \%)$ & $5(62.5 \%)$ \\
\hline Cândida / Candida & - & $4(57.1 \%)$ & $3(42.9 \%)$ \\
\hline \multicolumn{4}{|l|}{ Dermatofitoses / Dermatophytoses } \\
\hline Tinea corporis / Tinea corporis & $1(14.3 \%)$ & $1(14.3 \%)$ & $5(71.4 \%)$ \\
\hline Tinea pedis / Tinea pedis & $2(40 \%)$ & $2(40 \%)$ & $1(20 \%)$ \\
\hline Tinea cruris / Tinea cruris & $1(50 \%)$ & - & $1(50 \%)$ \\
\hline Tinea manuum / Tinea manuum & - & - & $1(100 \%)$ \\
\hline \multicolumn{4}{|l|}{ Leveduras / Yeasts } \\
\hline Candidíase cutânea / Cutaneous candidiasis & $1(12.5 \%)$ & $3(37.5 \%)$ & $4(50 \%)$ \\
\hline \multicolumn{4}{|l|}{ Fúngicas profundas / Deep fungal } \\
\hline Feo-hifomicose / Phaeo-hyphomycosis & $1(100 \%)$ & - & - \\
\hline \multicolumn{4}{|l|}{ Virais / Viral } \\
\hline Verruga vulgar / Verruca vulgaris & $5(7.5 \%)$ & $27(40.3 \%)$ & $35(52.2 \%)$ \\
\hline Condiloma acuminado / Condyloma acuminatum & $1(20 \%)$ & $2(40 \%)$ & $2(40 \%)$ \\
\hline Molusco contagioso / Contagious molluscum & - & - & $2(100 \%)$ \\
\hline Herpes simples / Herpes simplex & $3(75.0 \%)$ & - & $1(25 \%)$ \\
\hline Herpes-zóster / Herpes zoster & $1(50 \%)$ & $1(50 \%)$ & - \\
\hline \multicolumn{4}{|l|}{ Bacterianas / Bacterial } \\
\hline Foliculite / Folliculitis & $3(33.3 \%)$ & $2(22.2 \%)$ & $4(44.4 \%)$ \\
\hline Ectima / Ecthyma & - & $2(100 \%)$ & - \\
\hline Micobacteriose / Mycobacteriosis & - & - & $1(100 \%)$ \\
\hline \multicolumn{4}{|l|}{ Parasitárias / Parasitic } \\
\hline Escabiose / Scabiosis & $2(25 \%)$ & $5(62.5 \%)$ & $1(12.5 \%)$ \\
\hline
\end{tabular}

\section{DISCUSSÃO}

Nos pacientes transplantados, as infecções cutâneas são de extrema importância, pois podem indicar a presença de doenças infecciosas sistêmicas. ${ }^{2,3}$

Vários fatores contribuem para a elevada freqüência de infecções fúngicas superficiais nesses pacientes. $\mathrm{O}$ risco de infecção depende de fatores como critérios diagnósticos, exposição aos fungos potencialmente patogênicos, diferenças geográficas, socioeconômicas, condições de higiene, além do tempo de uso de imunossupressores. ${ }^{1}$ Destes últimos, particularmente os corticóides causam espessamento e prolongam o tempo de eliminação da camada córnea, o que também pode favorecer as infecções e sua cronicidade. ${ }^{4}$

As infecções superficiais mais freqüentes são de origem fúngica $(41,4 \%)$, seguidas pelas virais $(38,5 \%)$ e

\section{DISCUSSION}

In transplant recipients, cutaneous infections are of extreme importance, though they may indicate the presence of systemic infectious diseases. ${ }^{2,3}$

Various factors contribute to raising the prevalence of superficial fungal infections in these recipients. The risk of infection depends on factors such as diagnostic criteria, exposure to potentially pathogenic fungi, geographical and socioeconomic differences, and conditions of hygiene, in addition to the duration of immunosuppressor use. ${ }^{1}$ Among the latter, corticoids especially cause thickening and prolonging of the elimination time of the corneal layer, which may also favor infections and its chronicity. ${ }^{4}$

The most frequent superficial infections are of fungal origin (41.4\%), following by viral (38.5\%) and bacteria 
Tabela 3: freqüência de dermatoses infecciosas em 208 pacientes transplantados renais. Table 3: frequency of infectious dermatoses in 208 renal transplant recipients.

\begin{tabular}{lcccc}
\hline \multicolumn{4}{c}{ Tempo de transplante / Time of transplant } \\
\hline Dermatoses / Dermatoses & $<1$ ano (42 Pacientes) & $1-5$ anos & \\
& $<1$ year (42 recipients) & $1-5$ years (77 recipients) & $>5$ anos (89 Pacientes) \\
& $\mathrm{n}=14$ & $\mathrm{n}=39$ & $\mathrm{n}=32$ \\
\hline Fúngicas superficiais / Superficial fungal & $\mathrm{n}=1$ & $\mathrm{n}=0$ & $\mathrm{n}=0$ \\
Fúngicas profundas / Deep fungal & $\mathrm{n}=10$ & $\mathrm{n}=30$ & $\mathrm{n}=40$ \\
Virais / Viral & $\mathrm{n}=3$ & $\mathrm{n}=4$ & $\mathrm{n}=5$ \\
Bacterianas / Bacterial & $\mathrm{n}=2$ & $\mathrm{n}=5$ & $\mathrm{n}=1$ \\
Parasitárias / Parasitic & $\mathrm{n}=30$ & $\mathrm{n}=78$ & $\mathrm{n}=78$ \\
Total & & \\
\hline
\end{tabular}

bacterianas $(5,8 \%)$.

Nas dermatomicoses superficiais, a mais freqüente pitiríase versicolor - ocorreu em maior número após o primeiro ano de transplante $(83,8 \%)$, o que também foi observado no estudo de Virgilli et al., em $69,8 \%$ dos casos. ${ }^{1}$

As infecções virais ocorrem quase exclusivamente por herpesvírus nos primeiros anos após o transplante enquanto as verrugas são de aparecimento tardio., Observaram-se verrugas vulgares em $32,2 \%$ da população estudada, percentagem semelhante à encontrada por outros autores, ${ }^{2}$ embora a freqüência de verrugas em pacientes transplantados renais apresente variação significativa, mais precisamente, de 20 a $70 \% .^{7}$ Encontrou-se ocorrência relativamente pequena de verrugas nos primeiros 12 meses após o transplante $(7,5 \%)$, em comparação à frequiência observada após cinco anos de transplante $(52,2 \%)$.

Nas onicomicoses, foi observada maior ocorrência de fungos em geral considerados contaminantes, como Aspergillus spp e Fusarium spp, diferindo de relatos na literatura, que aponta o $T$ rubrum $^{8}$ e o $T$ mentagrophytes ${ }^{1}$ como os agentes envolvidos mais freqüentes.

Infecções bacterianas simples são relativamente comuns nos primeiros anos após o transplante, sendo a foliculite mais rotineiramente encontrada nesse grupo de pacientes.

A escabiose é a parasitose cutânea mais freqüente, sendo característica a dificuldade em obter resposta terapêutica com as medicações antiparasitárias usualmente prescritas.

Com base na experiência de seguimento de 208 pacientes transplantados durante um ano, os autores sugerem que seja realizado acompanhamento dermatológico desses pacientes, uma vez que as dermatoses infecciosas são muito comuns e sua frequiência aumenta consideravelmente após o primeiro ano de transplante (Tabela 3). infections (5.8\%).

In superficial dermatomycoses, the most frequent pityriasis versicolor - occurred in greater incidence after the first year of transplant (83.3\%), which was also observed in the study conducted by Virgilli et al. in $69.8 \%$ of cases. ${ }^{1}$

Viral infections occurred almost exclusively due to the herpes virus during the first years after the transplant, while warts apparently appear later. ${ }^{5,6}$ Verruca vulgaris were observed in $32.2 \%$ of the study population, a similar percentage to what other authors found, ${ }^{2}$ while the frequency of warts in renal transplant recipients shows significant variation, or more precisely from 20 to $70 \%{ }^{7}$ Relatively few occurrences of warts were found in the first 12 months after the transplant $(7.5 \%)$, as compared to the frequency observed five years after the transplant (52.2\%).

In onicomycoses, there was a higher incidence observed in general of fungi considered to be contaminants, like Aspergillus spp and Fusarium spp. This differs from reports in the literature, which points instead to $\mathrm{T}_{\text {rubrum }}{ }^{8}$ and $\mathrm{T}$ mentagrophytes ${ }^{l}$ as the most frequently involved agents.

Simple bacterial infections are relatively common during the first years after the transplant, with folliculitis being the most routinely found in this group of recipients.

Scabiosis is the most frequent cutaneous parasite, for which it is characteristically hard to obtain a therapeutic response with the antiparasitic medication usually prescribed.

Based on the results of the year-long follow-up involving the 208 transplant recipients, the authors suggest that a dermatological follow-up of the recipients be carried out, since infectious dermatoses are very common and their prevalence increases considerably after the first year from the transplant. (Table 3). 


\section{REFERÊNCIAS / REFERENCES:}

1. Virgili A, Zampino MR, La Malfa V, Strumia R, Bedani PL. Prevalence of superficial dermatomycoses in 73 renal transplant recipients. Dermatology 1999;199:31-34.

2. Barba A, Tessari G, Boschiero L, Chieragato GC. Renal transplantation and skin diseases: review of the literature and results of a 5-year follow-up of 285 patients. Nephron 1996;73:131-136.

3. Abel E. Cutaneous manifestations of immunosuppression in organ transplant recipients. J Am Acad Detmatol 1989;21:167-79. 4. Selvi SG. Kamalam A, Ajithados K, Janaki C, Thambiah AS. Clinical and mycological features of dermatophytosis in renal transplant recipients. Mycoses 1999;42: 75-78.

5. Bencini PL, Montagnino G, De Vecchi A, et al. Cutaneous manifestations in renal transplant recipients. Nephron 1983;34:79-83. 6. Lugo-Janer G, Sánchez JL, Santiago-Delpin E. Prevalence and clinical spectrum of skin diseases in kidney transplant recipients.
J Am Acad Dermatol 1991;24:410-4.

7. Barba A, Tessari G, Talamini G, Chieragato GC. Analysis of risk factors for cutaneous warts in renal transplant recipients. Nephron 1997;77:422-426.

8. Aly R. Ecology and epidemiology of dermatophyte infections. J Am Acad Dermatol 1994;31:S21-S25.

ENDEREÇO PARA CORRESPONDÊNCIA: / MAILING ADDRESS: André Vicente Esteves de Carvalbo Av. Guaíba, 4680 casa 07 Vila Assunção

Porto Alegre RS 91900-420

Tel/Fax: (51) 3286-5150

E-mail:avec@plugin.com.br 